\title{
THE MILITARY, WAR AND SOCIETY: THE NEED FOR CRITICAL SOCIOLOGICAL ENGAGEMENT
}

\author{
Lindy Heinecken, ${ }^{1}$ \\ Dept of Sociology and Social Anthropology, Stellenbosch \\ University
}

\begin{abstract}
Sociology offers a distinctive way of seeing and explaining the social world within which we live, as well as the events and institutions that shape it. Given this, it is surprising that the study of war by sociologists has been largely at the margins of the discipline. This has not always been the case, if one reflects on the work of the founding fathers of sociology - Marx, Weber and Durkheim. While the 'sociology of war' still does not feature strongly within the discipline, this article shows that sociology provides a critical lens through which to analyse military and warfare, as well as to show how violent conflict affects society. To illustrate this, reference is made to various leading social theorists and sociologists who inform our

Scientia Militaria, South African

Journal of Military Studies, Vol

43, No. 1, 2015, pp. 1-16.

doi : $10.5787 / 43-1-1107$

current understanding of collective violence and war in this era of globalisation. To end the discussion reference is made to the place of military sociology as a sub-field focusing on the military institution and some of the key
\end{abstract}

\footnotetext{
${ }^{1}$ Acknowledgement: This article is based in part on my inaugural address, titled The military, war and society: 'The Achilles heel' of sociology and the need for reflection, Stellenbosch University, 11 February 2014. I have chosen to publish this article in Scientia Militaria: South African Journal of Military Studies for a number of reasons. Firstly, to show my appreciation to the South African Military Academy for the contribution this institution has made to my career as a 'military' sociologist. Secondly, to sensitise South African scholars studying the military to the immense body of literature within the field of sociology that can deepen our understanding of violent conflict and war.
} 
texts and issues addressed by sociologists.

\section{Introduction}

Throughout history, war has led to epochs of social change that have transformed the face of human society. Even when there is relative peace, violent conflict and war remain omnipresent, which explains why most nation states continue to have their own armed forces. If there was no threat of violence, why spend vast amounts of scarce resources on an institution trained to inflict lethal force against others for security and protection? In essence, this is can be ascribed to the fact that human beings are prone to conflict, evidenced by the on-going violent conflicts in today's world. This results in untold misery for those affected, as societies become ripped apart and those affected are left to rebuild their lives. This raises the question why sociology as a discipline, with its strong conflict analysis tradition and focus on humankind, has not given the study of war much prominence. ${ }^{1}$ In fact, some claim that the study of war and collective violence is "the Achilles heel of sociology" and by implication, a disciplinary weakness. ${ }^{2}$

This is indeed a shortcoming if one considers the catastrophic effect that war and violent conflict have on society. While some sociologists have paid attention to military matters, this has been mostly in an interdisciplinary or a specialist area applied to a specific issue, ${ }^{3}$ or left to military theorists and strategists. ${ }^{4}$ Few use the conceptual tools provided by the discipline of sociology to analyse the military and violent conflict, and the effect this has on society. As Siebold points out, "their focus has been more of a continuing dialogue than an accumulation of theoretical and practical evidence that one might call the knowledge of the sub-field". 5 Sociology, in fact, has been an invisible discipline in the study of war and society, as reflected in its absence from key sociological textbooks. ${ }^{6}$ Despite the pervasiveness of war and violent conflict in the world today, sociologists in general have failed to engage with it, which has contributed to its marginalisation. This has been less so in the United States, but certainly the case among sociologists in Europe and elsewhere. One merely has to look at who is generating the knowledge in the field to grasp this.

In this article, I argue that sociological enquiry is not only necessary but also essential to understand violent conflict and the underlying causes of war today. To start the debate, reference is made to the contributions of the founding fathers of sociology to our understanding of violence and war. Thereafter, reference is made to some of the work of leading social theorists and sociologists who inform our understanding of the causes and consequences of violence and war for society. This is by no means a comprehensive overview of the scholarly work in the field. For 
this, one must turn to the work of Malešević, which in part prompted the writing of this article. ${ }^{7}$ The purpose here is merely to draw attention to the work of some influential sociologists to deepen our understanding of violent conflict, war and the military, which holds the monopoly of collective violence.

\section{Grand social theorists and the study of war}

So why do we see the disappearance of the study of the military and warfare from sociological discourse? The most common explanation cited for this is the foundational heritage of the Enlightenment, which, rather than seeing war and violence as structurally intrinsic to social life, perceived it as irrational and bound to dissipate with modernity. ${ }^{8}$ Whilst this is partly true from a Western perspective, the main reason why the study of the military has remained peripheral to mainstream sociological analysis can be ascribed to the nature and effect of the two world wars on humankind, and the relative peace that followed. The distaste for war and violence on the part of the public in the West was shared by many post-WWII sociologists. This, according to Malešević, led to "the hegemony of anti-militarist social theory that cleansed sociology from its militarist heritage" and implied that even the works of the classical social theorists are interpreted in strictly pacifist terms. ${ }^{9}$ This has not always been the case, and becomes clear when one reflects on the work of the founding fathers of sociology.

Early European sociologists, such as Karl Marx, Max Weber and Emile Durkheim, were critically engaged with the effect of war on social development, and with the military's relationship with larger society. In fact, this, together with the growth of industrial capitalism, was central to their understanding of social change and modernity. ${ }^{10}$ Both Marx and Weber analysed the matter primarily in relation to the influence of the military and war on the modern capitalist state, albeit from different ontological perspectives. On the one hand, Marx's theory of social change inevitably implied an interest in the mechanics of collective violence by the state, which, according to him, was a mere extension of capitalist interest. On the other, there was the working class seeking to transform the social order through revolution, which inevitably implied confrontation with the state's military forces. As such, Marx saw capitalism as the root cause of war, and contingent upon the existence of class divisions. ${ }^{11}$ While I acknowledge that this is a somewhat reductionist interpretation of Marx, his understanding and analysis of contemporary warfare and revolution remain relevant to the sociological study of war, as so aptly outlined by Giddens, in his work The nation state and violence. ${ }^{12}$ Even though the conflicts of the $20^{\text {th }}$ century have not been rooted in the fierce class struggles anticipated by 
Marx, many were influenced, if not determined, by economics and the exploitation by elites.

Of the three classical social theorists, Weber was most explicit in his explanations of the military as an instrument of power and force, emphasising the link between politics and violence, and the importance of the state's control over the monopoly of violence. ${ }^{13} \mathrm{He}$ emphasised the centrality of the military to state power. For Weber, a state is only a state when it is able to hold the exclusive right to authorise the legitimate use of physical force within its territory (something that many African states lack). ${ }^{14}$ As such, he places the military at the core of his analysis of power, as the most coercive tool at the disposal of the state. Weber's conception of the monopoly of violence as a symbol of state strength is still relevant today, albeit challenged due to the power and influence of non-state actors, which have caused the state to lose control of the monopoly of violence. ${ }^{15}$ Nonetheless, Weber's measure of the legitimate control and management of violence to provide state security or protection to its citizens continues to be used as an indicator of state strength.

Weber's contribution to our sociological analysis of the military does not end here, but extends to his work on bureaucracies. This emerged from his analysis of the military as a prototype for the modern state and the way an ideal type bureaucracy (like the military) should function. ${ }^{16}$ This is reflected in his use of concepts such as "discipline, obedience to formal norms, formal authority, rationale division of roles and attributes, competence and loyalty to an impersonal legitimate power", ${ }^{17}$ which are all central to our understanding of the general processes of rationalisation and bureaucratisation of society. Although Weber never completed his military sociology, ${ }^{18}$ his study of bureaucracy alludes to the dangers a corrupt and politicised bureaucracy can pose to society. ${ }^{19} \mathrm{He}$ points out the dangers the merging of traditional Weberian legal-rational bureaucratic models of command and control with patrimonial systems based on patronage pose to governance. How neopatrimonialism disrupts legal-rational bureaucracies and can lead to the abuse of power, is especially relevant for an understanding of the abuse of power by elites, corruption and the underlying causes of protest and violence in Africa, including South Africa. ${ }^{20}$

In comparison to Marx and Weber, Durkheim was a pacifist who considered violence to be a largely irrational, anachronistic feature of life. ${ }^{21}$ With his emphasis on cohesion and the need to establish consensus in society, he appeared almost disinterested in the question of social conflict. This is not to say that he ignored the influence of the military and war on society, but this was a subtext in his work as stated by Mukherjee, "it was theorised by caveat, by silence and implied as present 
by its absence". ${ }^{22}$ Even though Durkheim's work never theorised violence, his understanding of the effect of anomie and social disintegration on society is of practical value, and enables us to discern the effect and consequences of war on society. ${ }^{23}$ Based on this, one can actually see how war actually creates large-scale anomie, destroys the social fabric of society, and can evoke states of normlessness. As pointed out in a recent publication by Mukherjee, if nothing else, Durkheim highlights the important link between social cohesion and consensus in the process of preventing conflict and resolving it. ${ }^{24}$

Despite these insights, what the founders of modern social theory hardly foresaw was quite how savage and destructive the most recent wars in the world would be. Nor could they envisage how globalisation and information technology, and the social change these evoke, would influence warfare. This is why there is concern about the disappearance of the study of war and society by sociologists. ${ }^{25}$ To illustrate this, a cursory study of introductory sociology textbooks shows that scant attention is paid to the military, war and peace studies, and where such information does exist, it is usually as part of a sub-section of political sociology. This led Ender and Gibson to conclude, "the military is an invisible institution" to students of sociology. ${ }^{26}$ This is compounded by the fact that very few universities, internationally and in South Africa, offer a specialist course in the sociology of war. $^{27}$

Consequently, students of sociology may well be led to believe that the military and war are of little importance to human society. The implication of this is that such students will fail to understand the causes and consequences of war, the effect of militarisation on society, as well as the link between conflict, security and development. This is the Achilles heel of sociology, a disciplinary weakness which has meant that the study of war has been left largely to those working in the field of political, international and security studies, criminology and law. ${ }^{28}$ The fact that war hardly figures in the major sociological debates in $20^{\text {th }}$-century social theory means that war is seen as external to the main processes of social change - which it clearly is not.

\section{The sociology of violence and war}

This is not to say that sociology as a discipline has been completely devoid of the study of the military, war and their effect on society. According to Lang, sociologists focusing on these issues can be broadly placed in three categories:

- $\quad$ those dealing with the military's relationship with the state; 
- those who use sociological theories to analyse war and the effect of collective violence on society; and

- those focusing specifically on the military establishment, its nature and effect on society. ${ }^{29}$

Within the context of this article, it is not possible to refer to all the scholarly works in these respective areas; a few that have dealt with the military's relationship with the state, the connection between globalisation and war, and lastly societal factors that affect the functioning of the military establishment are merely mentioned in passing.

The military, the state and violence

In terms of the first focus - the military's relationship with the state - one can begin with the seminal work of the renowned sociologist $C$ Wright Mills, which remains key to our understanding of how the military, political and corporate elites consolidate their power and influence and control society. ${ }^{30}$ Even though Mills' emphasis was mainly on capital, class and its relation to the state, and less so on the military or militarism, his insights remain relevant to our understanding of how elites consolidate their power and use the military as part of their arsenal to project economic and political power. This is aptly reflected in the more recent work of Noam Chomsky, ${ }^{31}$ who has been particularly critical of how corporate elites shape state policy and use the military as a means to advance neo-liberalism and other social polities under the banner of democracy and individual freedom. He explains this in relation to how the United States consistently uses its dominant military power and military industrial complex to support or repress certain political regimes in its own economic or ideological interest. ${ }^{32}$ The social and political injustice this evoke, underlie some of the reasons for terrorism today.

Another influential sociologist who has brought collective violence back into focus is Anthony Giddens, who shows how transformations in the economy, politics and culture continue to be shaped and influenced by war. ${ }^{33} \mathrm{He}$ defines warfare, alongside capitalism, industrialisation and surveillance, as one of the major institutional clusters of modern society. This contribution stands out as a major theoretical analysis of the nature of the modern nation state and its association with the means of waging war. To some extent, his insights tie in with those of Michael Mann who explains how various sources of social power - ideological power, political power, military power and economic power - feed into each other to shape society. ${ }^{34}$ This work has been widely acclaimed as one of the classic works of contemporary sociology, and is expanded upon in a later publication. ${ }^{35}$ Here, Mann 
shows how interrelationships between states (mostly modern states), war and the economy (mostly capitalist economies and class relations) all need to be given equal weight in our understanding of processes that influence social change. ${ }^{36}$

Still focusing on the state, one is compelled to turn to the work of Zygmunt Bauman to understand how a state can manipulate the military for not only economic, but also ideological purposes. ${ }^{37}$ Bauman was perplexed by how a modern, highly civilised state like Germany could get ordinary citizens to commit such human atrocities in a seemingly rational and impersonal way during the holocaust. Drawing on the work of Weber, Bauman explains this in terms of the dangers that highly efficient bureaucracies, a product of modernity, can produce. He argues that a culture of rule following can create conditions under which morality becomes detached from rationality, resulting in "a system where rationality and ethics point in opposite directions where humanity is the loser". ${ }^{38}$ The question then is whether such actions are limited to highly regulated and controlled totalitarian regimes, or whether they can emerge in democracies. Michael Mann, in The dark side of democracy, suggests that they can. ${ }^{39}$

Mann points out some of the more nefarious features of democracy and the way these carry with them the seeds for the majority to tyrannise the minority. By referring to past and present cases of genocide, he produces a grand theory, which explains that ethnic cleansing is not something of the past, but a facet of our modern democratic age. ${ }^{40} \mathrm{He}$ argues that it is particularly multi-ethnic countries undergoing a transition to democracy that are prone to experience different degrees of ethnic cleansing and genocide. These conditions arise where there are deep unresolved tensions, which are often fuelled by outside intervention. According to Mann, it is particularly these kinds of political regimes that are most likely to experience deepseated internal ethnic rivalries and warfare. As such, it is of particular relevance to those of us trying to come to grips with the causes and consequences of ethnic conflict and war in Africa, the complex processes that underline this, and how this can possibly be prevented or exacerbated by intervening United Nations and African Union peacekeeping forces.

Violent conflict, war and globalisation

A number of sociologists have tried to explain the nature and causes of war and violent conflict in recent times in relation to the transformative power and influence of economic globalisation. Here I once more turn to the work of Zygmunt Bauman who, in his book Liquid modernity, examines the shift from 'stable' modernity (associated with rule making) to unstable postmodernity (fluidity of 
rules), which he claims is fuelling so-called 'new wars'. ${ }^{41}$ His central argument is that "liquid modernity generates new forms of insecurity, fear and threat that are extra-territorial and cannot be contained or resolved within the framework of nation states". ${ }^{42}$ He draws attention to the effect that the use of technologically advanced weapons, used from a distance, and the new way of warfare of the West affect weak states, and the insecurities and conflict this creates at local level. His arguments are insightful at numerous levels, from the factors that motivate the interventions to the effect this has on how warfare is conducted, and the morality thereof.

Complementing the work of Bauman is that of Martin Shaw, who spells out the implications that the use of high-tech weapons to minimise the political and military risk holds for governments, especially where these risks are transferred onto civilians of targeted countries. ${ }^{43}$ The argument is that the transference of the risks of warfare onto civilian populations, whose deaths are explained as merely collateral damage or unavoidable accidents of war, exposes governments to even more risks through the hostility and tensions this creates, both at home and in the nations affected. He raises these issues with reference to the wars in Iraq and Afghanistan, and the crisis this poses for the Western way of war. His work raises important questions related to governance, the rules of war and global justice, and provides us with a critical view of how superpowers are affecting international relations at various levels. ${ }^{44}$

Similarly, Mary Kaldor has sought to explain how the forces of globalisation are changing the nature and practice of war. According to Kaldor, the enforcement of neo-liberal economic policies is weakening already weak states, reducing their capacity to provide security and exercise control over their territory. She explains how this opens up the space for insurgent groups and criminal networks to flourish, which in turn generates conflict and tensions at local level. ${ }^{45}$ These conflicts are complex and extremely difficult to counter, as they transcend the boundaries between warfare (between states), organised crime and violations of basic human rights. ${ }^{46}$ Although Kaldor's 'new war paradigm' has been criticised as "not new", 47 she maintains that they are due to the effect that economic globalisation has on fuelling these 'new' predatory wars. As such, they differ from previous forms of warfare as they are premised not on geopolitical or ideological concerns, but on the effects of globalisation on identity politics. ${ }^{48}$

An interesting dimension of the work of all three these scholars, Bauman, Shaw and Kaldor, is the emphasis placed on how these 'new wars' have shifted the ratio of human casualties onto civilians, and the implications this holds for the societies affected. What is somewhat astounding, is that these authors do not actively engage with the gender dimensions of war and how gender inequality, 
patriarchy and masculinity feed into a culture of violence, and why sexual violence has become such an effective (and cheap) weapon of war. In response to this in a more recent article together with Chinkin, Kaldor addresses the matter and points out the effect that war has on the construction of gender and how these 'new wars' have a significant gender dimension. ${ }^{49}$ The use of tactics that include the systematic rape of women as a weapon of war has become an issue of great concern, resulting in a Global Summit to End Sexual Violence in Conflict in London, in June 2014, to find ways to prevent and deal with the causes and consequences of this scourge. ${ }^{50}$

While much has been written on this subject, to really understand war and gender one should begin by reading the seminal text on this subject by Joshua Goldstein, which is a good starting point for those wishing to understand the historical and theoretical debates on women and war. ${ }^{51}$ To grasp why sexual violence is such an effective weapon of war, one needs to understand the effect of patriarchy, as well as how masculinities feed into a culture of violence. For this, key sociological texts inform our understanding in this regard, namely the works of Sylvia Walby, James Messerschmidt and Robert Connell. ${ }^{52}$ Combined, Walby, Messerschmidt and Connell provide us with the overarching theories of gender relations that equip us to analyse the underlying power dynamics that lead to genderbased violence both within the context of war as well as post-war societal contexts. The use of rape as a war strategy aims specifically to destroy the bonds of trust between individuals, families and communities - the social capital that holds societies together. 53

Understanding how social capital is created is especially important within the context of war, for two reasons. While on the one hand, social capital is the substance that holds societies together and is essential to foster peace and development, on the other it can also generate conflict. Especially where bonds of trust are exploited along existing fault lines of race or ethnicity, it can fragment societies and fuel wars on the basis of identity, as Kaldor points out. ${ }^{54}$ To understand the various dimensions of 'social capital', one is of course compelled to engage with the work of French sociologist Pierre Bourdieu, ${ }^{55}$ who refers to social capital as the invisible glue that enables societies to function. The concept, however, is best explained by Robert Putnam, who describes how different forms of social capital bonding, bridging and linking capital - are created, and how necessary this is if societies are to build the required social and political cohesion for them to prosper. ${ }^{56}$.

There is one other general sociologist who warrants mentioning, before looking at the various contributions of those who have focused specifically on the military, or who are loosely defined as 'military sociologists'. This is the work of 
Erving Goffman, and his analysis of how 'total institutions', like the military, function. Total institutions are places where the identities of people are purposefully changed by the institution, through a process of socialisation, to accept a different set of values and behaviour. Goffman's explanation of how this occurs and affects individuals and their behaviour helps to understand how civilians are moulded into soldiers by the military institution, as well as how this affects their ability to reintegrate back into civilian society once they leave the total institution (military). ${ }^{57}$

Sociology of the military

Whereas in the previous section the focus was on the theories of various general sociologists, which serve as useful analytical and conceptual tools, military sociologists have tend to focus on specific issues, often in an applied way. This is because they are often employed at military academies or research institutions that require or push them to do empirical research on specific issues that affect the functioning of the military. This is reflected in both the topics that form the chapters of the book edited by Giuseppe Caforio, ${ }^{58}$ as well as the more recent four-volume publication by David Segal and James Burk. ${ }^{59}$ This is a good reflection of some of the themes addressed by sociologists, including civil-military relations, the experiences and consequences of war in contemporary times, force restructuring, issues of equality and diversity, to name but a few. In this section, reference is made to some of the literature and issues with which military sociologists have engaged.

After World War II, a so-called 'second generation of sociologists' began to conduct social research on the armed forces, which was of a more applied nature. ${ }^{60}$ This commenced with the empirical sociological research conducted by Samuel A Stouffer on the military establishment and military life, which provided the foundation for many leading works that followed. ${ }^{61}$ This included the work of Morris Janowitz, which remains one of the seminal works in the area of civilmilitary relations. ${ }^{62}$ This is a subject that has straddled the sociological/political debate, as reflected in the exchange between Samual P. Huntington ${ }^{63}$ and Janowitz on this subject. Following this, the first major textbook on military sociology, by Charles Coates and Roland Pellegrin appeared, which addressed organisational changes within the United States military and compared this with European forces, on matters related to military life, race relations and the role of women in the military. ${ }^{64}$ Many of these works focus on specific challenges facing the military and they are often interdisciplinary in nature. All these studies used sociology as a lens to study the military, but largely failed at theory building. This remains one of the criticisms of this sub-field of sociology which, according to Guy L Siebold, has meant that military sociology has never had a clear theoretical or issue-driven 
center. ${ }^{65}$ Some attempt to overcome this was made by Charles C Moskos, John A Williams and David R Segal who present a general theoretical model of national military transformation. ${ }^{66}$

What is strikingly absent from this latter book is the lack of attention given to the effect that the implementation of neo-liberal economic policies and employment practices are having on defence transformation. Not one of the chapters, for example, engages with the issue of the privatisation of military work even though the book is focused on the military profession and institution. This has been a topic of far greater interest to political scientists, such as Peter Singer ${ }^{67}$ and Deborah Avant ${ }^{68}$ with their focus primarily on the state, and the economics, politics and legal dimensions of the privatisation of security. What they did not capture was the effect that the privatisation of security was having on the military profession. An attempt to address this was made by Heinecken in an article titled "Outsourcing public security: The unforeseen consequences for the military profession". Here it is argued how outsourcing of military work to the private sector is eroding the intellectual and moral hegemony of the armed forces and that the long-term implications of this are not yet fully realised. ${ }^{69}$

This is not to say that this has been a field totally neglected by sociologists. How changes in broader society affect military work and the military profession have been key interests of sociologists. Already in the early seventies, Moskos ${ }^{70}$ developed the institutional/occupational drift model to show that those joining the military are not doing so because it is a calling, but because it is a job. Debates on this were captured in a book by Moskos and Wood, which stimulated a host of research studies on the topic. ${ }^{71}$ However, this book was written at a time when military service was still considered a life-time career, and before the shift to an allvolunteer force. Since the 1990 s, military service has become increasingly more segmented, with employment becoming short-term, conditional and transitional, where loyalty is not necessarily reciprocal. At the same time, military personnel have become more questioning, less receptive to authority and more assertive in defending their rights. ${ }^{72}$ This has placed the unitarist style of managing employee relations under strain, and in some cases, this has given rise to pressures for some form of independent representation or unionisation. How countries have reacted to these pressures are captured in the book by Bartle and Heinecken, which looks at how twelve different countries have dealt with these challenges. ${ }^{73}$

Managing diversity has become a theme of research among sociologists, not only because this resides within the disciplinary focus, but also because it has become a challenge for armed forces at different levels: 
- firstly, armed forces have become more diverse in terms of race and gender;

- $\quad$ secondly, they are now deployed and have to work with and alongside troops and civilian personnel from many different nations; and

- thirdly, the environments in which they are deployed require an understanding of different cultures.

The ways armed forces deal with issues of diversity differ substantially, as forces are largely influenced by the political, cultural and ethnic influences emanating from broader society. A good overview of some of the challenges armed forces face is captured in Managing diversity in the armed forces edited by Joseph Soeters and Jan van der Meulen, which looks at these issues within a theoretical and comparative context. ${ }^{74}$ While the latter publication focuses mainly on issues of diversity within armed forces, the more recent publication by Joseph Soeters and Phillip Manigart addresses the effect that diversity has on the operational environment and the need for intercultural competence by military personnel on peace missions. ${ }^{75}$ Both these edited volumes provide a good understanding of how important issues of cultural diversity within the military context have become.

\section{Conclusion}

One of the difficulties in writing this article was where to draw the line, which sources had to be included or excluded, and based on which criteria. This was to some extent a personal reflection of some of the seminal works within the discipline that could deepen our understanding of violent conflict and the effect this has on society. For a more comprehensive account of the sociology of war from a historical and theoretical perspective, it is necessary to engage with the work by Sinisa Malešević. This is a bold attempt to highlight the relevance of the discipline, and to reintroduce the study of collective violence and war back into mainstream sociology where it belongs. ${ }^{76}$

The intention of this article was merely to highlight some key works by leading sociologists that could assist us in understanding the root causes and the consequences of violent conflict and war on society. Whether we like it or not, this remains an integral part of human experience, and continues to shape the social world we live in. Sociologists have long concerned themselves with trying to understand what drives social change and how new forms of social order are created. Although they have largely distanced themselves from the study of war, what one does see in more recent years is a more concerted effort by sociologists to engage with this as reflected in the various seminal works highlighted in this article. 
Sociology provides a critical lens through which to analyse collective violence, armed conflict and the military, as well as how these events and the military as institution shape society. The value of critical engagement with social theory and sociological concepts is not only necessary, but also needed beyond the discipline. Political scientists, international relations scholars and military strategists will not be able to comprehend the complexities of violent conflict and war in this era of globalisation fully if they ignore the sociological dimension. Hopefully this article has been able to demonstrate the valuable contribution that the discipline of sociology can make in analysing and understanding the causes and consequences of war for humankind today.

\section{Endnotes}

${ }^{1}$ Giddens, A \& Sutton, PW. Sociology $\left(6^{\text {th }}\right.$ ed $)$. Cambridge: Polity Press, 2009, 1045.

${ }^{2}$ Malešević, S. "How pacifist were the founding fathers? War and violence and classical sociology". European Journal of Social Theory 13/2. 2010. 193.

${ }^{3}$ Walby, S. "Violence and society: Introduction to an emerging field in sociology". Current Sociology 61/2. 2012. 96.

${ }^{4}$ Giddens \& Sutton op. cit., p. 1045.

5 Siebold, G. "Core issues and theory in military sociology". Journal of Political and Military Sociology 29. Summer 2001. 141.

${ }^{6}$ Ender, M \& Gibson, A. "Invisible institution: The military, war and peace in pre 9/11 Introductory Sociology textbooks". Journal of Political and Military Sociology 33/2. 2005. 249-266.

${ }^{7}$ Malešević, S. The sociology of war and violence. Cambridge: Cambridge University Press, 2010.

${ }^{8}$ Malešević, "How pacifist were ..." op. cit., p. 17.

${ }^{9}$ Malešević, The sociology of war ... op. cit., p. 195.

${ }^{10}$ Walby op. cit., p. 1.

${ }^{11}$ Dandeker, C. Surveillance, power and modernity: Bureaucracy and discipline from 1700 to the present. New York: St. Martin's Press, 1989.

${ }^{12}$ Giddens, A. The nation state and violence. Volume two of a contemporary critique of historical materialism. Cambridge, MA: Polity Press, 1985.

${ }^{13}$ Weber, M. Weber: Political writings. Cambridge: Cambridge University Press, 1994.

${ }^{14}$ Ibid., p. 360.

${ }^{15}$ Giddens op. cit.

${ }^{16}$ Caforio, G. Handbook of the sociology of the military. New York: Kluwer Academic/Plenum, 2003.

${ }^{17}$ Nuciari, M. "Models and explanations for military organization: An updated reconsideration". In Caforio op. cit., p. 62.

${ }^{18}$ Miewald, R. "Weberian bureaucracy and the military model". Public Administration Review 30/2. 1970. 129. 
${ }^{19}$ Shields, P. "The bureaucracy in military sociology". In Callaghan, J \& Kernic, F (eds), Armed forces and international security, global trends and issues, New Brunswick: Transaction, 2003.

${ }^{20}$ Mkandawire, T. Neopatrimonialism and the political economy of economic performance in Africa: Critical reflections. Stockholm: Institute for Futures Studies, 2013.

${ }^{21}$ Kilby, J. "Introduction to special issue: Theorizing violence". European Journal of Social Theory 16/3. 2013. 261-272.

${ }^{22}$ Mukherjee, RS “Introduction”. In Mukherjee, RS (ed.), Durkheim and violence, Oxford: Wiley-Blackwell, 2010, 7.

${ }^{23}$ Mukherjee op. cit.

${ }^{24}$ Ibid.

${ }^{25}$ Malešević, The sociology of war ... op. cit., p. 194.

${ }^{26}$ Ender \& Gibson op. cit.

${ }^{27}$ Heinecken, L \& Visser, D. "Officer education at the South African Military Academy: Social science but no sociology". Armed Forces and Society 35/1. 2008. 145-161.

${ }^{28}$ Walby, op cit.

${ }^{29}$ Lang, K. Military institutions and the sociology of war. Beverly Hills, CA: Sage, 1972.

${ }^{30}$ Mills, CW. The power elite. Oxford: Oxford University Press, 1956.

${ }^{31}$ Chomsky, N. Profit over people: Neoliberalism and the global order. New York: Seven Stories Press, 1999.

${ }^{32}$ Haralambos, M \& Holborn, M. Sociology: Themes and perspectives $\left(7^{\text {th }} \mathrm{ed}\right)$. London: HarperCollins, 2008.

${ }^{33}$ Giddens op. cit.

${ }^{34}$ Mann, M. The sources of social power: A history of power from the beginning of $A D$. Cambridge: Cambridge University Press, 1986.

${ }^{35}$ Mann, M. States, war and capitalism: Studies in political sociology. Oxford:

${ }^{36}$ Ibid. Blackwell, 1988.

${ }^{37}$ Bauman, Z. Modernity and the Holocaust. Cambridge: Polity Press, 1989.

${ }^{38}$ Bauman op. cit., p. 206.

${ }^{39}$ Mann, M. The dark side of democracy: Explaining ethnic cleansing. Cambridge:

${ }^{40}$ Ibid. Cambridge University Press, 2005.

${ }^{41}$ Bauman, Z. Liquid modernity. Cambridge: Polity Press, 2000.

${ }^{42}$ Malešević, S. "How pacifist were ..." op. cit., p. 316.

${ }^{43}$ Shaw, M. The new Western way of war. Cambridge: Polity Press, 2005.

${ }^{44}$ Giddens \& Sutton op. cit., p. 2042.

${ }^{45}$ Kaldor, M. New and old wars: Organized violence in a global era $\left(2^{\text {nd }}\right.$ ed). Cambridge: Polity, 2007.

${ }^{46}$ Giddens \& Sutton op. cit., p. 1052. 
${ }^{47}$ Newman, E. "The 'New Wars' debate: A Historical Perspective is needed". Security Dialogue 35/2. 2004. 173-189.

${ }^{48}$ Kaldor, M. "In defence of new wars". Stability 2/1. 2013. 1-16.

${ }^{49}$ Chinkin, C \& Kaldor, M. "Gender and new wars". Journal of International Affairs 67/1. 2013. 167-187.

${ }^{50}$ United Kingdom Government. "Global summit to end sexual violence in conflict”. 2014. <https://www.gov.uk/government/topical-events/sexualviolence-in-conflict> Accessed on 15 July 2014.

${ }^{51}$ Goldstein, G. War and gender: How gender shapes the war system and vice versa. Cambridge: Cambridge University Press, 2001.

${ }^{52}$ See Walby, Theorizing patriarchy op. cit.; Messerschmidt, J. Masculinities and crime: Critique and reconceptualisation of theory. Rowman and Littlefield: 1993; Connell, RW. Masculinities. Cambridge: Polity, 1995.

${ }^{53}$ Meager, S.'Rape of the Congo: Understanding Sexual violence in the conflict in the Democratic Republic of Congo". Journal of Contemporary African Studies, 28/2. 2010. 119-135.

${ }^{54}$ Kaldor, New and old wars ... op. cit.

${ }^{55}$ Bourdieu, P. Distinction: A social critique of the judgement of taste. London: Routledge \& Kegan Paul, 1984. Also see Bourdieu, P. "The forms of capital". In Richardson, JG (ed), Handbook of theory and research for the sociology of education, New York: Greenwood, 1986.

56 Putnam, R. Bowling alone: The collapse and revival of American community. New York: Simon and Schuster, 2000.

${ }^{57}$ Goffman, E. Asylums: Essays on the social situation of mental patients and other inmates. Garden City, NY: Anchor, 1961.

${ }^{58}$ Caforio op. cit.

${ }^{59}$ Segal, DR \& Burk, J. Military sociology. New York: Sage, 2012.

${ }^{60}$ Nuciari op cit., p. 62.

${ }^{61}$ Stouffer, S. The American soldier: Adjustment during army life. Princeton, NJ: Princeton University Press, 1949.

${ }^{62}$ Janowitz, M. The professional soldier: A social and political portrait. Glencoe: The Free Press, 1960.

${ }^{63}$ Huntington, S. The soldier and the state: The theory and politics of civil-military relations. Cambridge, MA: Belknap Press of Harvard University Press, 1957.

${ }^{64}$ Coates, CH \& Pellegrin, RJ. Military sociology: A study of American military institutions and military life. University Park, MD: Social Science Press, 1965.

${ }^{65}$ Siebold op. cit., p. 142.

${ }^{66}$ Moskos, CC, Williams, JA \& Segal, DR (eds). The postmodern military. London: Oxford University Press, 1999.

${ }^{67}$ Singer, P. Corporate warriors: The rise of the privatized military industry. Cornell: University Press, 2003. 
${ }^{68}$ Avant, D. The market for force: The consequences of privatizing security. Cambridge: Cambridge University Press, 2005.

${ }^{69}$ Heinecken, L. "Outsourcing public security: The unforeseen consequences for the military profession". Armed Forces and Society 40/4. 2014. 625-646.

${ }^{70}$ Moskos, CC. "From institution to occupation: Trends in military organisation". Armed Forces and Society 4/1. 1977. 41-54; Moskos, CC. "Institutional/occupational trends in armed forces: An update". Armed Forces and Society 12/3. 1986. 377-382.

${ }^{71}$ Moskos C \& Wood, FR (eds). The military: More than just a job? Washington, DC: Pergamon-Brassey's, 1988.

${ }^{72}$ Boene, B, Van Bredow, W \& Dandeker, C. "The military in common-risk societies: Elements of comparison among nine countries of West, Central and East Europe". In Kuhlmann, J \& Callaghan, J (eds), Military and society in the 21st century Europe: A comparative analysis, Hamburg: Transaction Publishers, 2000, 305-27.

${ }^{73}$ Bartle, R \& Heinecken, L (eds). Military unionism in the post-Cold War era: A future reality. London: Routledge, 2006.

${ }^{74}$ Soeters, J \& Van der Meulen, J. Cultural diversity in the armed forces: An international comparison. London: Routledge, 2007.

${ }^{75}$ Soeters, J \& Manigart, P. Military cooperation in multinational peace operations: Managing cultural diversity and crisis response. London: Routledge, 2008.

${ }^{76}$ Malešević, "How pacifist were ..." op. cit. 